\title{
Procedure for risk assessment of initiation and progression of oxidation processes during development of pyrite ore deposits
}

\author{
Gennady Einbinder ${ }^{1 *}$, Natalia Mitishova ${ }^{2}$, Dmitry Radchenko ${ }^{2}$, and Egor Knyazkin ${ }^{2}$ \\ ${ }^{1}$ Association of Mining Expert Centres, 107078, Moscow, Russia \\ ${ }^{2}$ Federal State Budgetary Institution of Science, Institute of Comprehensive Exploitation of Mineral \\ Resources named after academician N.V. Melnikov of the Russian Academy of Sciences, 111020, \\ Moscow, Russia
}

\begin{abstract}
In the modern conditions, the scale of subsoil transformation in the process of mineral extraction is characterized by an increased risk of accidents, often accompanied by man-made disasters. In this regard, hazard analysis and accident risk assessment is the most important scientific and technical task, the solution of which is based on methods for identification of hazards, study of development trends and assessment of consequences of theoretically possible accidents. In relation to development conditions of sulfide ore deposits, only an accident risk assessment with determination of the possible accident hazard degree, as well as preparation and timely correction of measures aimed at reduction of accident risks can ensure an acceptable level of industrial safety at the hazardous production facility.

Keywords: pyrite ores, oxidation, spontaneous combustion, fire hazard, procedure, risk assessment, compensating measures.
\end{abstract}

\section{Introduction}

Russian mining enterprises with underground mining methods are hazardous production facilities of strategic importance. Therefore, when designing them, great attention is paid to regulatory compliance with industrial safety requirements. At the same time, in Russia, a number of deposits show a stable trend of outbreak and spread of underground fires resulting from sulfide oxidation with self-heating of ores [1].

One of the main reasons for this problem is that in the modern conditions, the industrial safety system at the enterprise is based on statistical data on the number of accidents, incidents and injuries and it does not provide a forecast of development of typical and nontypical scenarios, therefore, it does not allow for effective management of industrial safety. To prevent spontaneous combustion of pyrite deposits and ignition of sulfide dust, it is necessary not to wait for accidents, incidents and injuries, but to identify existing hazards, assess and rank the risks of initiation and development of hazard scenarios, and take measures aimed at preventing the occurrence of undesirable situations [2]. In this regard,

*Main author: geo-science@mail.ru 
relevance of implementing and developing a risk-based approach to ensuring endogenous fire safety at the Russian mining enterprises remains high.

\section{Theoretical studies}

During underground and combined development of sulfide ore deposits, safe and efficient development of reserves requires quantitative assessment of the parameters relating to progression of the interdependent deformation, oxidation and gas-thermodynamic processes. This is caused by transition of sulfides to the gas phase at high (over $250^{\circ} \mathrm{C}$ ) temperatures with the increase in porosity, cavitation, fracturing of the mass, oxidation of minerals, with activation of aerodynamic connections between the underground mine workings and the pit atmosphere and air circulation from the mine ventilation system through a technologically disturbed pyrite ore and rock mass into the pit.

A complex field of stresses and deformations associated with the influence of the rock mass underworking by open and underground mine workings occurs during combined open-underground mining. It is important to note that during design of open-pit mining operations, stability of the sides, determination of the maximum slope angles and depth of the pit are generally conducted without regard to the weakening effect of subsequent underground mining. As a result of the underground work expansion during ore extraction outside the limiting outline in the pit sides and base, the prism of side supports is unloaded and, as a consequence, growth of deformations with opening of the existing and initiation of the new man-made fractures, which become active channels of the underground mine connection with the surface atmosphere takes place. Through these channels, air oxygen actively circulates via cracks in the minerals of sulfide-containing rocks, as a result of their contact with oxygen, development of exogenous processes of heating and spontaneous combustion of sulfides is initiated. That is why during combined development of pyrite ore deposits, exogenous physical and chemical processes shall be considered in conjunction with geomechanical processes caused by mining work expansion outside the pit outline, and aerogasodynamic processes determined by the method, scheme and ventilation system of an underground mine.

The main purpose of the accident risk analysis is determination of the accident hazard degree of the facility under study (mine) to prevent risk of damage to life, human health, environment, and property of individuals and legal entities. Consistent risk assessments of the ore oxidation process propagation will ensure early implementation and timely adjustment of technological, organizational and technical measures, and preparation of recommendations for minimization of accident risk to the acceptable level. This will contribute to implementation of measures that reduce the scale of the accident consequences and the extent of environmental and economic damage.

The issue under consideration is particularly important in the light of the prospects for integrated development of sulfide ore deposits, as fight and suppression of sulfide fires is much more complex, even compared to fires in coal deposits. In case of major accidents, such as the accident at the Sibay underground mine in 2018-2019, serious social and economic disasters happen in the mining region. At the same time, the scale of negative environmental consequences is so impressive that it is difficult to assess them due to the large-scale and prolonged impact on the atmosphere, lithosphere, hydrosphere and biosphere of the region and they are accompanied by serious social consequences.

According to the Procedural Guidelines [3] "...at various stages of the life cycle of a hazardous production facility, the main goal of accident risk analysis is achieved by setting and solving appropriate tasks depending... " on the specific mining situation. Review of the recommendations in these Guidelines allowed us to systematize the stages of accident risk analysis in the form of a flowchart shown in Figure 1. 


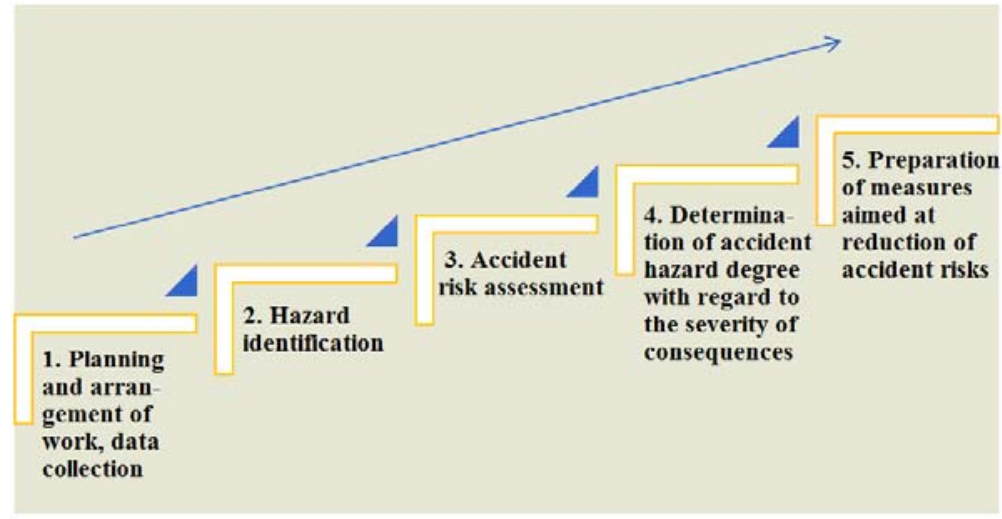

Fig. 1. Stages of accident risk analysis in case of spontaneous combustion of ores

The studies previously performed by the authors [4-5] in the field of initiation and progression of oxidation processes in the Russian pyrite mines provided for collection and analysis of information to identify accident hazards during underground and combined development of pyrite ore deposits in Russia. Hazard identification was performed in accordance with the development method used at the specific deposit.

Table 1. Results of hazard identification in combined open-underground mining

\begin{tabular}{|c|c|c|}
\hline $\begin{array}{c}\text { Hazards resulting in } \\
\text { incidents/ } \\
\text { accidents at the } \\
\text { mine }\end{array}$ & Accident progression stages & Accident consequences \\
\hline $\begin{array}{l}\text { Scenario S1. Leaving } \\
\text { the broken rock mass } \\
\text { in the underground } \\
\text { mine face for more } \\
\text { than the established } \\
\text { incubation period of } \\
\text { spontaneous } \\
\text { combustion }\end{array}$ & $\begin{array}{l}\text { Forming of the fire source in the broken rock } \\
\text { mass in the pit - fire spread to the neighboring } \\
\text { areas - lack of measures to eliminate the rock } \\
\text { pile - fire spread in the pit sides and base - fire } \\
\text { in the underground mine }\end{array}$ & $\begin{array}{l}\text { Toxic damage to the } \\
\text { mine workers - heat } \\
\text { stroke - injury and death } \\
\text { of the workers - } \\
\text { contamination of the } \\
\text { atmosphere and } \\
\text { hydrosphere, loss of } \\
\text { equipment }\end{array}$ \\
\hline $\begin{array}{l}\text { Scenario S2. } \\
\text { Abandonment of the } \\
\text { pit without } \\
\text { maintaining the sides } \\
\text { and providing access } \\
\text { to the pit }\end{array}$ & $\begin{array}{l}\text { Deformation of the pit sides - initiation of } \\
\text { fracturing in the pit sides - violation of the } \\
\text { aerological mode at the underground mine - } \\
\text { uncontrolled oxidation process of sulfide ores } \\
\text { and host rocks in the pit - emission of harmful } \\
\text { substances of chemical decomposition in the } \\
\text { form of sulfur dioxide and other impurities - } \\
\text { fire at the underground mine }\end{array}$ & $\begin{array}{l}\text { Toxic damage to the } \\
\text { mine workers - heat } \\
\text { stroke - injury and death } \\
\text { of the workers - } \\
\text { contamination of the } \\
\text { atmosphere and } \\
\text { hydrosphere, loss of } \\
\text { equipment - pit } \\
\text { abandonment }\end{array}$ \\
\hline $\begin{array}{c}\text { Scenario S3. } \\
\text { Air leakage from the } \\
\text { underground mine to } \\
\text { the pit }\end{array}$ & $\begin{array}{l}\text { Lack of control of the ventilation network } \\
\text { parameters - shift of balance between supply of } \\
\text { the main ventilation unit and the outlet air } \\
\text { volume - air influx into the fractured mass of } \\
\text { sulfide ores, air leakage into the pit - formation } \\
\text { of a fire source - development of a mine fire - } \\
\text { lack of preventive measures }\end{array}$ & $\begin{array}{l}\text { Toxic damage to the } \\
\text { mine workers - heat } \\
\text { stroke - injury and death } \\
\text { of the workers - } \\
\text { contamination of the } \\
\text { atmosphere and } \\
\text { hydrosphere, loss of } \\
\text { equipment }\end{array}$ \\
\hline
\end{tabular}

For conditions of combined development of Gayskoe, Shanuch, Kyzyl-Tashtygskoe, Vesenne-Aralchinskoe and Sibayskoe deposits, hazards that can cause accidents involving spontaneous combustion of sulfide ores in the course of combining the open-pit and 
underground mining at the subsoil under development were summarized. Results of the hazard identification are generalized in Table 1.

Based on the research results presented in [4-5], hazard identification allowed us to prepare the following typical scenarios of spontaneous combustion of ores for subsequent risk assessment. All chains of events, the consequences of which may lead to a major event - an accident as a result of their cumulative impact were analyzed.

When calculating the probability of accidents ( $\mathrm{P}$, units per year), research data from scientific publications [4-5], known methods [6-11], data from Rostechnadzor (Federal Environmental, Industrial and Nuclear Supervision Service of Russia), or, in the absence of published facts, expert assessment methods were used.

Typical scenario S1 (Table 2). Spontaneous combustion of sulfides as a result of leaving the rock mass pile for a period exceeding the established incubation period. Probability of the accident initiated as a result of leaving a loosened pyrite mass is determined based on the following series of probabilities:

$$
\left.P_{S 1}=P_{1}+\left(P_{2}+P_{3}+P_{4}+P_{5}+P_{6}\right) \times P_{7} \times P_{8}+P_{9} \text { (units/year }\right)
$$

where $\mathrm{P}_{1}=10^{-6}$ - probability of an error in estimation of the sulfides (sulfur) content; $\mathrm{P}_{2}=$ $10^{-2}$ - probability of untimely shipment of rock mass due to the shutdown of the area following on the technological chain; $\mathrm{P}_{3}=10^{-3}$ - probability of untimely shipment of rock mass due to an accident at the mine; $\mathrm{P}_{4}=10^{-4}$ - probability of untimely shipment of rock mass due to the personnel errors; $\mathrm{P}_{5}=10^{-6}$ - probability of the mining enterprise shutdown due to force-majeure circumstances (quarantine, emergency, etc.); $\mathrm{P}_{6}=10^{-4}$ - probability of sabotage, terrorist attack; $\mathrm{P}_{7}=0,1$ - probability of creating conditions for air access to the broken rock mass; $\mathrm{P}_{8}=10^{-3}$ - probability of absence of the measures to eliminate the fire source; $\mathrm{P}_{9}=10^{-3}$ - probability of design errors (no requirements for determining the incubation period).

The typical scenario S2 includes an aerological risk - spontaneous combustion resulting from violation of the ventilation mode in the mine workings. Probability of an accident initiation due to violation of the ventilation mode is determined based on the following series of probabilities:

$$
P_{S 2}=P_{1} \times\left(P_{2}+P_{3}+P_{4}+P_{5}+P_{6}\right) \times P_{7} \times P_{8} \times P_{9} \text { (units/year), }
$$

where $\mathrm{P}_{1}=10^{-3}$ - probability of air leakage through a fractured mass of sulfide ores and rocks, or through a broken rock mass; $\mathrm{P}_{2}=10^{-2}$ - probability of untimely shipment of rock mass due to the shutdown of the area following on the technological chain; $\mathrm{P}_{3}=10^{-3}-$ probability of untimely shipment of rock mass due to an accident at the mine; $\mathrm{P}_{4}=10^{-4}$ probability of untimely shipment of rock mass due to the personnel errors; $\mathrm{P}_{5}=10^{-6}-$ probability of the mining enterprise shutdown due to force-majeure circumstances (quarantine, emergency, etc.); $\mathrm{P}_{6}=10^{-4}$ - probability of sabotage, terrorist attack; $\mathrm{P}_{7}=10^{-3}$ - probability of the rock mass deformation and formation of artificial crack systems; $\mathrm{P}_{8}=$ $10^{-3}-$ probability of absence of the measures to eliminate the fire source; $\mathrm{P}_{9}=10^{-3}-$ probability of lack of the air volume control on the intake and return flow during ventilation of the mining area.

The typical scenario S3 considers spontaneous combustion of ores resulted from pit abandonment without maintaining the sides and providing access to the pit during the combined open-underground development of pyrite ore deposits. Probability of spontaneous combustion caused by deformations of the pit sides and growth of crack systems is determined based on the following series of probabilities:

$$
P_{S 3}=P_{1} \times P_{2} \times P_{3} \times\left(P_{4}+P_{5}\right) \text { (units/year), }
$$

where $\mathrm{P}_{1}=1$ - probability of development of deformation processes in the pit sides and base composed of sulfides resulted from underground mining; $\mathrm{P}_{2}=10^{-3}$ - probability of aerologic mode violation at the underground mine; $\mathrm{P}_{3}=1$ - probability of formation of crack system with opening sufficient to establish active aerodynamic relations between the 
pit and the underground mine; $\mathrm{P}_{4}=10^{-2}$ - probability of design errors in terms of lack of requirements for the pit abandonment with preservation of transport communications; $\mathrm{P}_{5}=$ $10^{-3}$ - probability of lack of fire source elimination.

Based on the obtained estimates of the probability and severity of the accident consequences, according to the risk assessment matrix $[6,11]$, for each accident scenario, the risk level for combined open-pit mining was quantified (Table 2).

Data analysis of Table 2 shows that under conditions of mining enterprises, in case of implementing the scenario S1 associated with spontaneous combustion at open-pit mining facilities, the risk level is acceptable and extremely unlikely. This is confirmed by operational practices of the mining enterprises.

It was determined that the scenario S2 is characterized by the risk level "Practically possible" with disastrous consequences. This means that in the event of initiation and development of this scenario in the absence of containment of the accident sources, numerous accidents (injuries, death of personnel), significant environmental and material damage, estimated at hundreds of million rubles are likely to happen.

For the scenario S3, calculations established that spontaneous combustion of ores resulted from the pit closure without maintaining the sides and providing access to the pit during combined open-pit mining is likely and can occur at the mining facilities, which is also confirmed by mining practice. The established risk level is "Research and risk reduction are required". Given the established fundamental regularities of initiation of such accidents, as well as the fact of interrelation between deformation processes and spontaneous combustion of ores, preparation of measures compensating for the increased operation risk of combined development of sulfide ore deposits is required to reduce the risk level in the projects.

Table 2. Estimation of incident probability and risk level

\begin{tabular}{|c|c|c|c|c|}
\hline Incident & $\begin{array}{c}\text { Probability } \\
\text { of an } \\
\text { incident, } \\
\text { 1/yearr }\end{array}$ & $\begin{array}{c}\text { Qualitative } \\
\text { indicator of the } \\
\text { probability } \\
\text { level }\end{array}$ & $\begin{array}{c}\text { Qualitative } \\
\text { indicator of the } \\
\text { severity of } \\
\text { consequences }\end{array}$ & Risk level \\
\hline $\begin{array}{c}\text { S1. Leaving the rock } \\
\text { mass pile for a period } \\
\text { exceeding the } \\
\text { established } \\
\text { incubation period of } \\
\text { spontaneous } \\
\text { combustion }\end{array}$ & $10^{-14}$ & $\begin{array}{c}\text { E (highly } \\
\text { unlikely) }\end{array}$ & 4 (serious) & $\begin{array}{c}\text { RAC } \\
\text { (acceptable) }\end{array}$ \\
\hline $\begin{array}{c}\text { S2. Aerological risk. } \\
\text { Ventilation mode } \\
\text { violation in the mine } \\
\text { workings }\end{array}$ & $10^{-14}$ & $\begin{array}{c}\text { E (highly } \\
\text { unlikely) }\end{array}$ & $\begin{array}{c}5 \\
\text { (disastrous) }\end{array}$ & $\begin{array}{c}\text { RP } \\
\text { (practically } \\
\text { possible) }\end{array}$ \\
\hline $\begin{array}{c}\text { S3. Spontaneous } \\
\text { combustion of ores as } \\
\text { a result of pit } \\
\text { abandonment without } \\
\text { maintaining the sides } \\
\text { and providing access } \\
\text { to the pit }\end{array}$ & $10^{-5}$ & $\begin{array}{c}\text { C (Probable. } \\
\text { May happen) }\end{array}$ & $\begin{array}{c}\text { RH } \\
\text { (disastrous) }\end{array}$ & $\begin{array}{c}\text { (research and } \\
\text { risk reduction } \\
\text { required) }\end{array}$ \\
\hline
\end{tabular}

Based on the risk-oriented analysis, the need for preparation and implementation of compensating measures for development of pyrite ore deposits was found out, namely:

1. Conditions for keeping the access of workers and mining equipment, ensuring the ability to extinguish mine fires in case of spontaneous combustion of ores and rocks, shall 
be provided in the projects for combined open-underground development of sulfide ore deposits at the stage of transition from open-pit mining to underground operations.

2. Installation of thermal sensors in the rock mass between the abandoned pit working and the underground mine workings shall be provided for combined development to control the temperature dynamics in the broken pyrite rock mass.

3. Monitoring of the deformation process progression and risk of the rock mass fracturing growth shall be ensured.

4. Control of the air flow parameters at the underground mine with elimination of imbalance on the intake and return air flow shall be ensured. Measures aimed at searching for air loss places and their timely correction shall be provided.

5. Measures for mine fire fighting in the pit sides and base by drilling boreholes, fire fighting with available means, followed by concreting/silting the source of sulfide fire shall be developed.

6. In the absence of the above measures in the project, possibility of establishing such requirements shall be provided in the safety justification, preparation of which shall ensure transition to alternative development methods.

\section{Conclusions}

1. Based on the performed research, technological recommendations for ensuring the mining safety with regard to the spontaneous combustion factor of sulfides in the combined development of pyrite ore deposits were proposed.

2. As a result of the performed analysis of mining-geological and mining-engineering conditions of development of the sulfide ore deposits under study and hazard analysis, risk of initiation and progression of accidents at the mining facilities was estimated. Hazard identification was performed for the facilities under study grouped by the development methods: open, underground, combined open-underground.

3. It was established that for open-pit mining facilities, the risk level of initiation and progression of accidents associated with combustion of the broken rock mass (face, dump, ore stockpile) is characterized as acceptable which indicates an extremely low probability of the fire outbreak.

4. It is shown that in case of combined deposit development, scenario of ores spontaneous combustion after the pit abandonment with leaving sulfide ores and rocks outside the pit outline in the absence of access to the pit during combined openunderground development, risk of the sulfides ignition is likely and requires preventive implementation of compensating measures. The established fundamental regularities of the accident progression based on the interrelation between deformation processes and spontaneous combustion of ores showed that to reduce the risk of sulfide ignition in the projects, preparation of measures compensating for the increased risk of sulfides spontaneous combustion during combined development of sulfide ore deposits is required.

The study was carried out with financial support of the Russian Foundation for Basic Research within the scientific project No. 19-35-90099

\section{References}

1. N.M. Tretyakov, D.V. Sedov, Human Activity Safety, 2(18), 221 (2020)

2. O.V. Vorobyova, Mining Informational and Analytical Bulletin, 12, 61 (2009)

3. Procedural Guidelines for Risk Assessment of Hazardous Industrial Facilities (2016) 
4. M.V. Rylnikova, D.N. Radchenko, G.I. Einbinder, E.N. Esina, Izvestiya TulGU (News of the Tula State University). Sciences of Earth, 2, 126 (2020)

5. M.V. Rylnikova, G.I. Einbinder, N.A. Mitishova, L.A. Gadzhieva, Izvestiya TulGU (News of the Tula State University). Sciences of Earth, 2, 139 (2020)

6. Risk Management in Regulatory Frameworks: Towards a Better Management of Risks (Geneve: United Nations Economic Commission for Europe, 2012).

7. GOST R 56275-2014 Risk management. Project risk management good practice guide.

8. GOST R ISO 14001: 2007 Environmental management systems. Requirements with guidance for use.

9. GOST R ISO 14004: 2007 Environmental management systems. General guidelines on principles, systems and support techniques.

10. GOST R ISO 31000:2010 (ISO 31000:2009) Risk management. Principles and guidelines.

11. GOST 27.310-95 Failure mode, effects and criticality analysis. Basic principles 